\title{
RUSSIAN INFORMATION PRESENCE AT THE BALKANS: CHALLENGES AND PROSPECTS
}

\author{
Evgeny N. Pashentsev ${ }^{1}$
}

Abstract: The article seeks to explore the role and the channels of Russia's information presence in the Balkans. Focusing first of all on the activity of the Russian media in the region, it also describes the activity of Russian public diplomacy institutions, foundations, public organizations, scientific associations, etc., which have developed a collaboration with civil society institutions of the Balkan countries in the interest of bilateral and multilateral cooperation.

When implementing strategic communication, the main attribution is the "synchronization of words" (information support of the state course) and "deeds" (long-term public policy) and how they will be perceived by target audiences. Thus, the very actions of the Russian state and its various representatives (both officials and a wide range of non-state actors), undertaken both in Russia and the Balkans, constantly project certain meanings into the minds of the audience. The most significant will be projections of real cases that objectively benefit both Russia and the Balkan countries themselves, for example, the creation of high-tech jobs and assistance in crisis situations.

Not only are new crises dangerous for Russia, but it is important for Russia not to lose the opportunities to strengthen relations with the Balkan countries and with all other countries that do not want to see Europe and the Balkans as only a chessboard of the great powers, or even worse the possible battlefield of a WW3.

Keywords: information presence, the Balkans, Russia, public diplomacy, strategic communication.

${ }^{1}$ Prof. DSc. Evgeny N. Pashentsev, Leading Researcher, Institute of Contemporary International Studies, Diplomatic Academy, Ministry of Foreign Affairs of the Russian Federation, Moscow. 


\section{RUSSIAN INFORMATION PRESENCE IN THE BALKANS}

Russia's information presence in the Balkans and its impact on relations with the Balkan countries and the overall situation in the region is understandable and of undoubted importance, not only in the context of the historical past, but above all in the present and future, whether it is in the economy, politics, culture, or security. Against the background of increasing international tension, compounded by mutual accusations of global and regional actors in the crisis associated with the coronavirus pandemic, the relevance of the topic of the article only increases.

There is an evident lack of research not only on the topic of the article but also on related topics (for example, on "the role of Russia's information influence in the Balkans") (Skovorodnikov, 2017, p. 184). The current article cites publications on strategic communication (General Staff of the Slovenian Armed Forces, 2019; Holtzhausen \& Zerfass, 2015; Pashentsev, 2012; 2014a, 2014b, 2018, 2020; Paul, 2011), public diplomacy (Seidov, 2017; Tsvetkova, 2017; Velikaya, 2019), and soft power (Borisova, 2015; Neymark, 2018; Nye, 2013). Expert assessments of the situation were received, as well as analytical materials and publications from a researcher at the National University of Political Science and Public Administration in Bucharest (Romania), Dr. Marius Vacarelu, and a researcher at the Institute of Political Science in Belgrade (Serbia), Dr. Maria Đoric.

The main volume of open sources directly related to the topic is represented by publications of analytical centers and researchers mainly from the European Union (Anderson, 2019; Eisentraut and de Leon, 2018; Janda and Víchová, 2019; Secrieru, 2019; Svárovský, Gurney, \& Kröger, 2019; Szpala, 2014; Víchová, 2019), which means that the information space of Europe, including the Balkan countries, is dominated by one-sided biased assessments of the Russian information presence (Stronski \& Himes, 2019, p. 10). This is reflected in the tone of Russia's representation in the media, not only in the Balkans but also in neighboring countries, including states that are only partially located on the peninsula (Burduja, 2018; Recorder, 2018; Voicu, 2018). Works on the topic of Russia's presence in Serbia (but primarily on the economic presence, contacts of Russian and Serbian political parties, and in some cases on the work of Russian media) are available in Serbian (see, for example, Antidot, 2018; Đurković, 2012; Đurović, 2019). 
The author expresses his gratitude for the analytical materials and publications received from Dr. Marius Vacarelu, the researcher from the National School of Political Science and Public Administration in Bucharest (Romania), and Dr. Marija Đorić, the research associate of the Institute for Political Studies in Belgrade (Serbia).

The research question. The article seeks to explore the role and the channels of the Russian information presence in the Balkans. Focusing first of all on the activity of the Russian media in the region, it also describes the activity of Russian public diplomacy institutions, foundations, public organizations, scientific associations, etc., which have developed a collaboration with civil society institutions of the Balkan countries in the interest of bilateral and multilateral cooperation.

The type of study. Qualitative research that collects and works with nonnumerical data and seeks to understand better the role of the Russian information presence in the Balkans and its functioning, including the current crucial period of struggle with COVID-19.

\section{THE MAJOR FINDINGS \\ RUSSIAN INFORMATION PRESENCE IN THE BALKANS: MAIN DIRECTIONS AND THEIR CURRENT STATE}

The Russian information presence in the Balkans is evident not only by the media but also by various actors who create information channels, from top officials of the state to a wide range of non-state actors. The channels of Russia's information presence in the Balkans include both the Russian media and the media of the Balkan countries themselves. Working with the local media is often difficult due to their frequent ownership by owners from the EU and the United States. But as we will see later, Russian news agencies are able to publish their materials in major media in the region. These channels can also be other mass media, such as social networks, as well as online services such as Booking.com. These are channels where reviews of Russia's actions in the international arena or Russian realities cannot be controlled by the Russian government.

All theoretical research about public diplomacy is worth little if there are no real working institutions. Among the dozens of NGOs that shape the image of Russia in the Balkans, the undisputed leaders are Rossotrudnichestvo, the 
Russkiy Mir Foundation, and the Alexander Gorchakov Public Diplomacy Fund (GF) (Mladenovich \& Ponomareva, 2016).

Rossotrudnichestvo is represented in the Balkan region in Albania, Bulgaria, Croatia, Greece, Macedonia, Montenegro, Serbia and Slovenia, by Russian centers of science and culture and representatives of Russian embassies (Rosstrudnichestvo, 2020).

Russkiy Mir has been operating in Serbia for quite a long time: it has offices in Belgrade, Novi Sad, and NIS; it also has offices in the Republic of Srpska (Banja Luka) and is expanding its activities to some other countries in the region (Russia Noah's Ark, 2019).

Since 2013, the GF has been implementing the scientific and educational program "The Balkan Dialogue" in the form of an annual international conference for young professionals in the fields of international relations, politics, economics, and history of the Balkan region, as well as for representatives of public organizations, local and regional self-government bodies and state structures, and journalists. Over the years, representatives from Belarus, Bosnia and Herzegovina, Bulgaria, Croatia, Greece, Macedonia, Moldova, Serbia, Slovakia, Slovenia, the Republic of Srpska, Russia, Ukraine, and Montenegro have participated in the conference (Ponomareva, 2017). Unfortunately, the program receives only modest coverage in the Russian media, on the website of the GF (Balkan Dialogue [Russian and English versions], 2020), where there are no conference outcome documents, but there are full texts of at least the most significant of the Russian-Balkan dialogue papers. (While for public diplomacy the texts are available both in Russian and in foreign languages, for true open access English-language versions are needed.) As we will see later, reports and documents of foundations and "think tanks" that have a negative attitude toward Russia are almost always available in English, the most widely used language of international communication in Europe.

Among the Russian media in the Balkans, and in particular, in Serbia, RT, Sputnik, and Voice of Russia are the leaders in audience coverage (www.glasrusije.rs). The largest Serbian daily newspaper Politika and the monthly Geopolitika contain the additions Ruska Reč and Rusija i Srbija published by Rossiyskaya Gazeta as part of Russia Beyond the Headlines Project (Szpala, 2014). Information received from the Sputnik Agency is transmitted by numerous local media outlets in Serbia, as well as by the Blic, Kurir, Informer, Večernje novosti and B92 portals. In addition, according to 
2018 data, about 40 Serbian Internet portals periodically broadcast Russia's point of view on important political topics (Kosovo and Metohija, Syria, and Eastern Ukraine) (Đurović, 2019).

Certain areas of implementation of the Russian information presence related to contacts through political parties and public organizations, as well as sports and religious diplomacy, which make a significant contribution to Russia's information presence in the Balkans but have limited scope for the purposes of this publication, are not analyzed in the current article.

Russia's information presence in the Balkans is one of the factors (but not the decisive one) for Russia's popularity in the Balkans, although the attitude toward it varies greatly from country to country. Serbia and Montenegro are countries where Russia's popularity is at a high level. Russia is more popular in Montenegro than in the US and the EU (Víchová, 2019, p. 29). An opinion poll conducted in July 2018 in Serbia showed that 21\% of respondents considered Russia the main source of financial assistance, compared to $24 \%$ who pointed to the EU, and $17 \%$ to China (Bechev, 2019 , p. 16). Under these conditions, the prospects for Russia's information presence may be rather favorable.

\section{PROBLEMS OF THE RUSSIAN INFORMATION PRESENCE IN THE BALKANS}

Russian state and non-state actors have to present their point of view and establish cooperation in the Balkans in the context of ongoing information warfare. This involves not only the media but also research institutes, in one way or another, connected with the governments of Western countries.

The publication of the Carnegie Endowment for International Peace is an example of a typical report on Russia's international activities: "Within Europe, the Balkans appear particularly vulnerable to fake or manipulated news narratives ... due to lagging education systems and poor political literacy. Russian news agencies also take advantage of cash-strapped Balkan news sources by providing content to local outlets for free or at extremely low cost" (Stronski \& Himes, 2019, p. 8). The Carnegie Foundation is formally a non-governmental organization, but its employees include a number of former US government officials. The foundation's president is 
former Deputy Secretary of State William Burns (Carnegie Endowment for International Peace, 2020).

The Organized Crime Corruption Reporting Project (OCCRP), founded in 2007 in Sarajevo by American journalist Drew Sullivan, who accused Russia of interfering in the internal affairs of North Macedonia, openly reports that it receives support in the form of grants from the US Agency for International Development (USAID) and the US State Department (OCCRP, 2020).

An actual example of the development of anti-Russian programs is the Kremlin Watch Strategy for Countering Hostile Russian Interference (Janda \& Víchová, 2019), published by the European Values Center for Security Policy in December 2019. The strategy proposes 20 measures that, according to the center's staff, the EU should take against Russia. The authors of the strategy proposed to increase funding for the EU's Eastern Strategic Communications Task Force (East StratCom Task Force) at the European External Action Service, transferring large funds to the sphere of psychological warfare (the goals which in a situation of aggravation of international relations can serve as strategic communication goals).

Noteworthy are the center's proposals to conduct regular surveys and in-depth sociological research to assess the extent of Russian influence (Janda \& Víchová, 2019, p. 9), bring EU sanctions to full compliance with US sanctions, counter not only the work of Russian nonprofit organizations but also the speeches of representatives of the Russian academic community (Janda \& Víchová, 2019, p. 14), and change the relationship with employees of Russian state media-for example, reconsidering their role as legitimate journalists, prohibiting them from participating in press conferences, and not giving interviews to them (Janda \& Víchová, 2019, p. 14).

The Konrad Adenauer Foundation (KAF) recommends that the EU implement public diplomacy in the region in two main areas: active counteraction to Russian propaganda and "smarter outreach to Western Balkan nations" (Eisentraut \& de Leon, 2018, p. 5). The foundation points out the need to translate EU strategic communication materials not only into English, Russian, and German but also into the languages of the Balkan countries, in addition to creating a mobile application that can be downloaded in various languages of the Western Balkans, and to sponsor the monitoring of social networks through the European Commission to track Russian propaganda (Eisentraut \& de Leon, 2018, p. 5). 
Some recommendations of the KAF may mean direct intervention in the internal affairs of the Balkan states. Thus, the KAF recommends that the EU "increase their pressure on regional leaders" who "misrepresent the EU's role in their countries" by "overstating Russia's assistance to their country": "EU institutions and member states should credibly threaten [italicization mine] to reduce or withdraw certain types of assistance should their activities not be adequately communicated" (Eisentraut \& de Leon, 2018, p. 8). At the same time, there are no promises to increase aid to those countries committed to the idea of European integration. Thus, a country that has essentially rejected Russia's aid may experience a deep crisis. We can already see this in the example of the ban on the export of medical products from the EU to the Balkan countries (PolitNavigator, 2020), despite their requests for assistance in the fight against the coronavirus.

Despite all the bias of such publications, it should be noted that they cover the problem in a comprehensive manner. Thus, the publications of the Carnegie Endowment for International Peace, the NATO StratCom Center of Excellence, and the European Values Center for Security Policy consider Russia's influence in the Balkans in various aspects-from the influence of Russia's economic presence in the life of the region to the cooperation of the Russian and Balkan media. Thus, Russia's actions are considered as operating at the strategic communication level. Accordingly, complex countermeasures are also proposed.

In our view, it is advisable to take into account the effectiveness of such analytical reports and articles in the development of Russian publications in order to critically (not manipulatively) prove to the Balkan audience the systemic influence of the EU, the US, and NATO in the region in selfish interests that infringe on the interests of the Balkan countries, but where and since such interests are actually present and such infringement takes place. A dubious publication about the Bolshoi Theater (Nemtsova, 2017) should not be answered in the same way. In a game of tabloids, it is unlikely that Russia will win strategically, even if some members of the public prefer the beautiful fairy tales of the Russian tabloids. Of course, when describing actions against the Russian media and their Balkan partners, it is necessary to refer to traditional European values, first of all, to the concept of freedom of speech.

High-quality Russian analytical products published with open access, including in foreign languages, require the development of scientific schools, providing research institutes and centers with funds not only for conducting 
the research itself but also for high-quality translation and editing in foreign languages. If an article is accepted in a highly rated international journal (and ideally such Russian journals are in great need), it is necessary to publish the article in an open-access format. Presenting scientific arguments that go beyond journalistic polemics is especially important against the background of periodic accusations of aggressive coverage by the Russian media regarding the situation in the Balkans (Antidot, 2018).

Despite the importance of cooperation between Russia and the Balkan countries in the energy sector, it is worth thinking about what high-tech industries, in which Russia is an innovator, can be developed in the Balkans. In this regard, we can agree with the Russian Ambassador to Serbia Alexander Botan-Kharchenko, that the opportunities of Russia and Serbia in the field of economic cooperation are not fully realized (Borisov, 2019). New knowledge and jobs in innovative industries themselves create the need to learn the language of the country that is leading in the field of innovation.

\section{RUSSIAN INFORMATION PRESENCE IN THE BALKANS THROUGH THE PRISM OF STRATEGIC COMMUNICATION}

Tools for increasing the information presence can include interaction with not only the media or the means of public diplomacy but also with the means of strategic communication. Most generally, strategic communication is the state's projection of certain vital and long-term values, interests, and goals into the conscience of domestic and foreign audiences. It is effectuated by means of adequate synchronization of multifaceted activities in all domains of social life, commonly with professional communication support. It is clear that such synchronization takes place in Russia nowadays (reflecting the dynamics of the unique national symbiosis of the old and the new, of the local and the adopted aspects of administration forms and methods of influencing public consciousness).

In order to usher in a qualitatively new level of development, it is vital for Russia to raise the efficiency of management in all domains of society. The increase in Russia's capacity for utilizing strategic communication might become one of the most efficient tools for developing new systems of this sort. It will decrease the burden on administrative and financial 
administration organs, have a real impact on the speed of economic growth, and reinforce Russia's international position (including in the Balkans) as well as its state security. It is worth noting that we are not talking about replacing physical action with communication manipulation mechanisms Russia needs real progress, not its propagandistic imitation.

Without strategic deeds, there is only a set of long-term communication goals on principal issues, but whether such deeds are adequate or truthful is an open question. Without relevant state deeds, the communication is very often nothing more than vague propaganda, even if it is strategic in intent. For example, First Secretary of the Communist Party of the Soviet Union Nikita Khrushchev, speaking on October 31, 1961, at the TwentySecond Congress of the party with a report on the project of the third program of the CPSU, said, "the current generation of Soviet people will live under communism." The document, which was adopted by the delegates of the Congress, also indicated the deadline for the completion of the "unfolded construction of communism"-20 years (Obeschania.ru, 2019). Of course, the Soviet people were a bit disappointed by the results of non-existent progress long before 1980. Later, false propaganda of the party elite was one of the reasons for the collapse of the USSR. However, it is not only good ideas that are deformed by wrong decisions. Sometimes, for example, synchronization of the wrong words, images, and deeds has led to global disaster. Efficient deeds (first the decisive and rather easy successes on the fronts of the Second World War, plus robbery of Untermenschen all over Europe) made the majority of Germans firmly believe in the genius of Hitler (with the help of very efficient Nazi propaganda). The result is well known: more than 50 million victims of German aggression. Effective synchronization of deeds, words, and images almost led to fascist world domination.

Thus, strategic communication has to be not only an efficient synchronization of deeds, words, and images but has to include an ethical and social dimension too. In a failed state you can find no state strategy and no state strategic communication. But there is no vacuum in the current world. Instead of national strategic communication, there always appears strategic communication of other states and/or non-state transnational groups, such as in current Libya, for example. Through a rise of progressive social forces coming to power, strategic communication may appear once again, or the state will be split forever like the USSR—or taken over by 
reactionary forces with their own interests and agenda-setting and relevant strategic communication. In failed states like Libya, such dilemmas are more or less evident. In still viable, more developed countries-yet in the group experiencing protracted crises-such processes are more difficult to detect. They are, however, no less real.

First, strategic communication is not only communication by itself but also communication through state deeds.

Second, it is incorrect to consider strategic communication primarily as a military tool; it is a strategic public administration tool (with a military dimension as well, of course).

Third, it is necessary to confront not only a wrong strategic communication in itself but also a state-run machine-if it supports itself utilizing a wrong means of development. This often involves the use of reactionary social groups. A reactionary state can follow on a weak strategic communication, and it is not bad at all for progressive forces. In the case where a reactionary, especially aggressive state follows efficient strategic communication, it may be extremely dangerous for the whole world if we are speaking about a rather powerful state or international union of states.

Fourth, progressive forces cannot underestimate the role of efficient strategic communication as a tool for progressive change. A progressive strategy without efficient means, based on advanced technologies, is objectively doomed to death.

When implementing strategic communication, the main attribution is the "synchronization of words" (information support of the state course) and "deeds" (long-term public policy) and how they will be perceived by target audiences. Thus, the very actions of the Russian state and its various representatives (both officials and a wide range of non-state actors), undertaken both in Russia and the Balkans, constantly project certain meanings into the minds of the audience. The most significant will be projections of real cases that objectively benefit both Russia and the Balkan countries themselves, for example, the creation of high-tech jobs and assistance in crisis situations. One of the most recent good examples of this is sending military planes carrying military physicians and medical equipment to Serbia to help it fight the coronavirus outbreak.

Real assistance can be the first step toward developing a full-fledged strategic communication of Russia that goes beyond the activities of fuel and 
energy companies in the region. Even now, Russia's assistance to European countries encourages a more appropriate attitude of the EU, not least to its own members. For example, after the Russian assistance to Italy was noted as a positive example for other countries by NATO Secretary-General Jens Stoltenberg (Dzhabrailov, 2020), President of the European Commission Ursula von der Leyen apologized to Italians for the lack of solidarity on the part of Europe in the fight against the coronavirus crisis (Balmer, 2020) and promised significant assistance in fighting its economic consequences.

\section{CONCLUSION}

Tensions in the international arena, including in the Balkan region, will not ease in the near future. Moreover, the opponents of Russia's rapprochement with the countries of the Balkans may become even more active, which will significantly hinder Russia's information presence in the region.

New crises in the Balkans are dangerous not only for the Balkan countries themselves but also for international security in general. It is important for Russia to strengthen its relations with the Balkan countries on a long-term basis. In the implementation of strategic communication of Russia, academic research in the languages of target audiences should be used as a means of scientific diplomacy. Comprehensive research on the Balkan region is necessary, but this is impossible without an established school of Balkan studies that is well funded at the state level.

It is advisable to establish continuous monitoring of the media of the Balkan countries, for which we can recommend using the media databases available from specialized business structures, such as Medialogy (Medialogia). It is desirable to develop communication strategies to respond to possible media campaigns designed to upset relations between Russia and the countries of the Balkan Peninsula. Cooperation in this area between researchers from Russia and the Balkans and other countries can have a positive effect because it is not about pulling the Balkans from one military bloc to another, but about turning them into a zone of international stability, and preventing them from becoming a springboard for direct aggression against Russia, which is in the interest of lasting peace in Europe.

Contacts with non-governmental organizations, among whose publications one can find works containing different views on political 
processes, can become an additional channel for both scientific and broader public diplomacy. In addition, in order to ensure mutually beneficial cooperation between Russia and the Balkan countries in high-tech areas, it would be advisable to find out how many students from the Balkans study in Russian universities and in what specialties. If there are many such students in the field of advanced technologies, it would be useful to organize competitions for the best student projects, possibly with subsequent internships in Russia and subsequent employment (first of all in the home country of a particular student, which can be done in cooperation with interested employers from the Balkan region). This would significantly increase Russia's reputation as a high-tech country in the Balkans. But such mutually beneficial results cannot be achieved without a progressive model of development of Russia and the Balkans based on a socially oriented economy, real democracy, and rapid implementation of the fruits of scientific and technological progress in the interests of the broader population strata.

\section{REFERENCES}

Anderson, L. (2019). Vulnerabilities to Russian influence in Montenegro. European Values Center for Security Policy.

Antidot (2018, May 31) Balkanska ofanziva kremaljskih paramedija [Balkan Offensive of Kremlin Media]. http://www.nspm.rs/prenosimo/ balkanska-ofanziva-kremaljskih-paramedija.html?alphabet=l.

Balkan Dialogue (English version). (2020). https://gorchakovfund.ru/en/ project/view/balkanskiy-dialog

Balkan Dialogue (Russian version). (2020). https://gorchakovfund.ru/ project/view/balkanskiy-dialog

Balmer, C. (2020, April 2). EU Commission apologises to Italy over coronavirus response, deaths push higher. Yahoo News. https://www.yahoo.com/news/eu-commission-apologises-italy-over145727277.html

Bechev, D. (2019). Russia's strategic interests and tools of influence in the western Balkans. NATO StratCom Center of Excellence.

Borisov, A. (2019, November 2). Posol RF v Serbii: Rossija uvelichit informacionnoe prisutstvie na Balkanah [Russian ambassador to Serbia: 
Russia will increase its information presence in the Balkans]. https:// rg.ru/2019/11/02/posol-rf-v-serbii-rossiia-uvelichit-informacionnoeprisutstvie-na-balkanah.html

Borisova, E. (Ed.) (2015). Soft power, mjagkaja sila, mjagkaja vlast'. Mezhdisciplinarnyj analiz: kollektivnaja monografija [Soft Power. Interdisciplinary analysis: $A$ collective monograph]. Flinta - Nauka.

Burduja, S. (2018, January 17). În Noul Război Rece, ruşii atacă cu o armă Made in URSS: Kompromatul [In the new Cold War, the Russians attack with a weapon made in the USSR: Compromising evidence]. https:// republica.ro/in-noul-razboi-rece-rusii-ataca-cu-o-arma-made-in-ursskompromatul

Carnegie Endowment for International Peace. (2020). William J. Burns. https://carnegieendowment.org/experts/1014

Đurković, M. (2012). Savremena ruska spoljna politika i Srbija početkom XXI veka [Contemporary Russian foreign policy and Serbia at the beginning of the XXI century]. Kultura polisa, 17, 1-26.

Đurović, J. (2019, June 21) Plasiranje ruskog narativa na Balkanu mnogo lakše nego na Zapadu [Placing the Russian narrative in the Balkans is much easier than in the West]. https://www.glasamerike.net/a/ prenosioci-ruskog-narativa-na-balkanu-mnogo-lakse-nego-na-zapadu/ 4967340.html

Dzhabrailov, K. (2020, April 1). Gensek NAT0 ocenil pomoshh' Rossii v bor'be s koronavirusom v Italii [NATO secretary general appreciated Russia's assistance in the fight against coronavirus in Italy]. https:// www.gorodovoy.spb.ru/news/gensek-nato-ocenil-pomosch-rossii-vborbe-s-koronavirusom-v-italii?utm_source=yxnews\&utm_medium= desktop\&utm_referrer=https $\% 3 \mathrm{~A} \% 2 \mathrm{~F} \% 2$ Fyandex.ru\%2Fnews

Eisentraut, S., \& de Leon, S. (2018). Propaganda and disinformation in the western Balkans: How the EU can counter Russia's information war. Facts \& Findings No. 294. Konrad Adenauer Stiftung.

General Staff of the Slovenian Armed Forces. (2019). Contemporary military challenges. Special issue: Strategic communication(s) and armed forces. General Staff of the Slovenian Armed Forces.

Holtzhausen, D., \& Zerfass, A. (Eds.) (2015). The Routledge handbook of strategic communication. Routledge. 
Janda, J., \& Víchová, V. (Eds.) (2019). Kremlin watch strategy for countering hostile Russian interference. European Values Center for Security Policy.

Mladenovich, M. \& Ponomareva, E. (2016). Publichnaja diplomatija Rossii: balkanskoe napravlenie [Russian public diplomacy: the Balkan direction]. https://interaffairs.ru/jauthor/material/1473

Nemtsova, A. (2017, June 12). Is something rotten at Moscow's Bolshoi Theater? https://www.thedailybeast.com/is-something-rotten-atmoscows-bolshoi-theater

Neymark, M. (2018). "Myagkaya sila”v mirovoy politike [Soft power in world politics]. Dashkov \& Co.

Nye, J. (2013, April 7). "Myagkaya sila" i amerikano-evropeyskie otnosheniya [Soft power and US-European relations]. http://smartpowerjournal.ru/ soft-power

Obeschania.ru. (2019). K 1980 godu v SSSR budet postroen kommunizm [By 1980, Communism will be built in the USSR]. Obeschania.ru. http://www.obeschania.ru/documents/promises/k-1980-g-v-sssrbudet-postroenkommunizm

OCCRP. (2020). About OCCRP. https://www.occrp.org/ru/about-us

Pashentsev, E. (2012). Kommunikacionnyj menedzhment i strategicheskaja kommunikacija [Communication management and strategic communication]. Moscow: ICSPSC.

Pashentsev, E. (2014a). Kommunikacionnyj menedzhment i strategicheskaja kommunikacija: sovremennye tehnologii global'nogo vlijanija i upravlenija [Communication management and strategic communication: Contemporary technologies of the global influence and management]. Moscow: ICSPSC.

Pashentsev, E. (2014b). Provocation as an element of strategic communications of the USA: The case study of Ukraine. Public Administration. Electronic Bulletin, 44, 149-175.

Pashentsev, E. (2018). Qualitative changes in modern technologies and their impact on Russia-EU relations. Public Administration. Electronic Bulletin, 69, 26-55.

Pashentsev, E. (Ed.) (2020). Strategic communication in EU-Russia relations: Tensions, challenges and opportunities. Palgrave Macmillan. 
Paul, C. (2011). Strategic communication: Origins, concepts, and current debates. Praeger.

PolitNavigator. (2020, March 17). V bundestage zaklejmili otkaz ES pomoch' Serbii [The Bundestag branded the EU's refusal to help Serbia]. https://www.politnavigator.net/v-bundestage-zaklejjmili-otkaz-espomoch-serbii.html

Ponomareva, E. G. (2017). Publichnaja diplomatija Rossii na Balkanah: problemy i perspektivy [Public diplomacy of Russia in the Balkans: Problems and prospects] In A. N. Proezdnikov (Ed.), Vneshnepoliticheskie interesy Rossii: istorija i sovremennost'. Sbornik materialov IV Povolzhskogo nauchnogo kongressa [Russia's foreign policy interests: History and modernity. Materials of the IV Volga Academic Congress]. Samara Humanitarian Academy.

Recorder (2018, September 25). Rusia face propagandă pe banii noștri. Guvernul României finanțează un site afiliat Sputnik [Russian propaganda on our money. Romanian government funds Sputnik affiliate site]. https://recorder.ro/rusia-face-propaganda-pe-baniinostri-guvernul-romaniei-finanteaza-un-site-afiliat-sputnik

Regnum (2020, April 3). Spiker EP: Zapadnye Balkany budut borot'sja s koronavirusom vmeste s ES [The speaker of the EP: the western Balkans will to fight coronavirus together with the EU]. https://regnum.ru/ news/society/2905281.html

Rosstrudnichestvo (2020, March 11). V Moskve obsudili rol' obshhestvennoj diplomatii v otnoshenijah Rossii s balkanskimi stranami [In Moscow, the role of public diplomacy in Russia's relations with the Balkan countries was discussed]. http://rs.gov.ru/ru/news/64992?category_id=9

Russia Noah's Ark. (2019, August 27). Nikita Bondarev: "Rossija na Balkanah hodit kak lunatic" [Nikita Bondarev: "Russia in the Balkans walks like a lunatic"]. https://rnk-concept.ru/57394

Secrieru, S. (2019). Russia in the western Balkans: Tactical wins, strategic setbacks. European Union Institute for Security Studies brief. European Union Institute for Security Studies.

Seidov, V. G. (2017). Znachenie publichnoj diplomatii v processe realizacii publichnoj politiki [The importance of public diplomacy in the implementation of public policy]. Mezhdunarodnye otnoshenija [International Relations], 1, 1-8. 
Skovorodnikov, A. V. (2017). Russia's use of "soft power" in the Balkans (based on the analysis of expert opinions on Internet resources). Diary of the Altai School of Political Research, 33, 183-187.

Stronski, P., \& Himes, A. (2019). Russia's game in the Balkans. Working Paper. Carnegie Endowment for International Peace.

Svárovský, M., Gurney, J., \& Kröger, S. (2019). How do EU Member States', Canadian and the United States intelligence agencies assess Russian and Chinese influence activities? Part II: Analysis of Russian \& Chinese influence in Central Europe. Konrad-Adenauer-Stiftung and the European Values Center for Security Policy.

Szpala, M. (2014, October 27). Russia in Serbia: Soft power and hard interests. Centre for Eastern Studies (OSW) Commentary No. 50. http://aei.pitt.edu/58198/1/commentary_150.pdf.

Tsvetkova, N. A. (2017). Publichnaja diplomatija pri D. Trampe: konec tradicijam ili klassika v novom ispolnenii? [Public diplomacy under D. Trump: the end of traditions or classics in a new version?], XXVI mezhdunarodnyj rossijsko-amerikanskij seminar v Sankt-Peterburgskom gosudarstvennom universitete: sbornik [XXVI International RussianAmerican Seminar at Saint Petersburg State University: Materials]. Saint Petersburg State University Press, pp. 125-128.

Velikaya, A. A. (2019). Publichnaja diplomatija Rossii i SShA: sravnitel'nye aspekty dvuh sistem i rol' v razvitii dvustoronnego dialoga [Public diplomacy of Russia and the United States: Comparative aspects of the two systems and the role in the development of bilateral dialogue]. Vestnik SPbGU. Mezhdunarodnye otnoshenija [St. Petersburg State University Bulletin. International Relations], 12(4), 500-517.

Víchová, V. (Ed.) (2019). Assessment of the Kremlin's malign influence in Bosnia and Herzegovina, Montenegro and North Macedonia. European Values Center for Security Policy.

Voicu, M. (2018). Matrioșka mincinoșilor. Fake news, manipulare, populism [Matryoshka of Liars. Fake News, Manipulation, Populism]. Editura Humanitas. 